\title{
The Vedic Mantra-The Psychology of the Inspired Word
}

\author{
MS Srinivasan* \\ Senior Research Associate, Sri Aurobindo Society, India
}

Submission: November 02, 2017; Published: November 10, 2017

*Corresponding author: MS Srinivasan, Senior Research Associate, Sri Aurobindo Society, Sri Aurobindo Society, No.11, Saint Martin Street, Puducherry -605001, India, Email: srinivasan@aurosociety.org

\section{Opinion}

The Mantra is an important part of the Vedic yoga. But what is exactly the Vedic mantra? We must remember here that the Vedic conception of the mantra is very different from the traditional religious conception of it as the repetition of a sacred word. Mantra for the Vedic Rishis was an integral part of their mystic sacrifice to the divine powers. It was used by Vedic sages not merely for invoking the help of the gods but also for many other more important spiritual purposes. This article is a brief review of the meaning and significance of the Vedic Mantra in a psychological perspective.

\section{The creative word}

First of all the mantra for the vedic sages is a potent means for creative self-expression of their realisations. It is the inevitable Word which expresses as faithfully and as perfectly as possible the vibration or sound-from of the supramental truth or idea realised by the sages in their consciousness. And, secondly, the Mantra is the means by which the truth seen is established and made an integral part of the consciousness of the seer. The creation of the Vedic mantra is not a mental activity; it originates from the superconscient part of the seer, received in the depth of his heart, brought forward by the contemplation of his conscious mind and finally breathed-out in the form of the inevitable word.

What is the basis of this great importance given by the Vedic Rishis to the creation of the Manthara? To answer this question we must go back to the Vedic theory of creation. In the Vedic thought, the word is considered as a great creative force. According to one of the Vedic schools of thought, universe is created by the Vac, the goddess of speech. Let us first examine the psychological basis of this Vedic conception.

\section{The sound, vibration and the word}

If we introspect a little, we can see that the origin of human speech is an inner sound forming into words or in other words an inner movement or vibration of consciousness, a movement of thought, feeling, sensation expressing itself through a set of words. Our human speech is in its essence the sound-form of a subjective movement of consciousness. We need not bother much here about the physiological process by which this inner movement is translated into the gross speech and word. We are here concerned mainly with the psychological and spiritual origin of the speech and word.

According to ancient Indian grammarians every inner movement of consciousness tends towards self-expression in the form of an inner sound, word and language even when it is not outwardly articulated in gross speech and word. The speech and the word are considered as creative because it gives a precise form to an inner movement of consciousness which would have otherwise remained inchoate and unmanifest. For in the Indian view creation is not forming something out of nothing but Srushti which means "loosing forth" into manifest form that which remains unmanifest. It the Vedic conception the process of human speech is a diminished figure of the process of the original creative Act which gives birth to the World. Now let us leap again from the psychological to the metaphysical plane to examine the validity of this Vedic concept.

\section{The eternal vibration}

One of the well-known and common ideas of all ancient occult and spiritual traditions of the world is the concept of creation proceeding from an eternal Vibration in the supreme Reality or the original existence. According to the Indian spiritual tradition when the absolute willed to create the world, this supreme will manifests as the original Vibration, Spanda, in its infinite being. This primal vibration is the Vedic Vac, the eternal Word which gives birth to the world.

This creative Vibration is normally equated with $\mathrm{OM}$, the original sound. But the vibration is not only "Sound" but also 
"Light"; it is at once "Light and Sound." For the essential nature of the creative power of the Reality is consciousness which is at once the eternal Light of Awareness which knows and reveals and an eternal Energy inherent in Light which creates. So the supreme creative Word is a rhythmic vibration of energy in the light of the creative consciousness of the Supreme, rta-chit or rtm-jyothi of the Vedas.

But creation of what? Not illusions but truths, truths of the divine Reality projected in its creative consciousness in the form of a harmony of creative ideas, rta, of the Vedas. Each creative idea is a luminous vibration of consciousness pregnant with a self-realising truth which unfolds itself in the cosmic evolution according to its own unique and inherent self-law swadharma. This harmony of creative vibrations of truth of things in the supreme consciousness of the Reality is the primal Word. The entire cosmic movement is nothing but rhythmic and progressive unfolding of this eternal creative vibration, the Vac, the word, $\mathrm{Om}$, in Space and Time. This is the Vedic theory of creation.

\section{The inner hearing and vision}

Now what is the relation of his Vedic theory of creation to the Vedic Mantra? The highest truth of things of life and nature is an eternal vibration of light and sound in the consciousness of the creative Divine and can be seen and heard by the inner spiritual vision and hearing of the Seer and Poet. The Vedic singer is at once a Rishi, the seer who has seen and a Kavi, the poet who has heard the Truth. The Mantra is the word-form of the luminous sound-body of truth. An ideal mantra must be the inevitable and inspired word which can exactly reproduce the rhythm and music of the sound-body or vibration of truth seen and heard by the inner vision and hearing of the seer. Thus creating the Mantra is the combined work of two spiritual faculties of revelation which sees and the inspiration which hears the truth. This is the reason why in the Indian tradition, the Veda is called as Sruthi, something "heard".

For the Rishi who fashions the Mantra, the function of
Mantra is to establish the power of truth seen and heard by him in the very substance of his consciousness and make it a part of his being. For the one who chants or hears the mantra, it can reproduce the vibration of truth in his consciousness and thereby lead him to the same experience and vision of the seer of the mantra.

\section{Sanskrit: the manthric language}

Sanskrit language in general and the Vedic Sanskrit in particular is believed to have such mantric power. For the Vedic mantras are called as chandas, which means "metres" and these metres are considered in the ancient Vedic tradition as the reflection of the cosmic metres, the Great Universal Rhythm, Rta, which governs the world. Sanskrit alphabet is based on certain fundamental root-sounds which can be made through the human vocal instruments. The Sanskrit grammar is based on the principle or intuition that there is a definite relationship between the sound, word and its meaning. Apart from this theoretical considerations, the manthric power of Sanskrit language is a well-tested fact even in our modern age. For some, both from the east and west, the mantric power of Sanskrit is a living spiritual experience.

For example, Vyas Houston, an American Sanskrit scholar, say in an interview: "Sanskrit seems to promote healing and generate inspiration whether you understand it or not. I spent many years chanting what I did not understand. But as I became proficient enough on chanting, more and more of the actual meaning come through. Now when I chant, I do understand the meaning. And it has aligned me much, much more deeply with the teaching, because I am getting the resonance as the meanings conveyed in its awesome body of sacred teachings [1]." This personal experience of a western Sanskrit scholar shows the tremendous spiritual-creative power inherent in this ancient Indian language.

\section{References}

1. (1992) Yoga International.

\section{Your next submission with Juniper Publishers} will reach you the below assets

- Quality Editorial service

- Swift Peer Review

- Reprints availability

- E-prints Service

- Manuscript Podcast for convenient understanding

- Global attainment for your research

- Manuscript accessibility in different formats ( Pdf, E-pub, Full Text, Audio)

- Unceasing customer service

Track the below URL for one-step submission https://juniperpublishers.com/online-submission.php 